\title{
BUDAPEST'S LARGE PREFAB HOUSING ESTATES: URBAN VALUES OF YESTERDAY, TODAY AND TOMORROW
}

\author{
MELINDA BENKÖ \\ Budapest University of Technology and Economics \\ E-mail: benko@urb.bme.hu
}

\begin{abstract}
In Budapest, one third of the population lives in large prefabricated housing estates. Therefore, this Modern heritage of the Communist period is one of the key issues of sustainable urban development. The majority of scientific studies on mass housing focus on economic and social aspects, so this research intends to approach the subject from the built-up environment. Taking the people's needs and Budapest's specific situation in relation to the challenges of sustainability as a starting point, the paper attempts to use the back-casting method based on social, economic and environmental trends. Defining a theoretically desirable future for this dominant type of urban housing, the analysis works backwards to understand their principal historic turning points. What are the values of large prefabricated housing estates? What were they, and what could they be? How can this modern and open urban form be sustained? What elements of the existing built environment will disappear, and what can be adapted in the transition process? By introducing three different scales - city, neighborhood and building, along with their subcategories - it is possible to recognize the effects of changing socio-economic conditions upon the built context and indicate problem-oriented, locally-minded interventions.
\end{abstract}

Keywords: housing estates, urban renewal, Budapest, sustainable urban neighborhood, assessment indicators, urban history

One of the biggest transformations of urban social fabric in Central and Eastern Europe (CEE) came about through the construction of large prefabricated housing estates. In Hungary, the mass housing policy utilizing prefabricated technology was initiated with the help of the first fifteen-year housing policy 1961-75 and the second five-year-plan development project 1961-65 (Körner 2006). In the politically and economically divided Europe of that time, professional reflection on modern housing and planning solutions remained absolutely international. France, the United Kingdom, Scandinavian countries and the Soviet Union were principal reference points for the Hungarian stakeholders. Following guidelines first from the International Congresses of Modern Architecture (CIAM), which operated between 1928-59 (for example, the La Sarraz Declaration from 1928, and the Athens Charter from 1933), then recommendations by Team 10, as the 
vanguard of urban and architectural theory between 1953-81, cities were planned and divided into modern functional zones. New units of city organization were developed everywhere - called new towns and micro-districts in the United Kingdom, villes nouvelles and grand ensembles in France, Großwohnsiedlung in Germany, тикрорайон (micro-districts) in the Soviet-Union, and lakótelep (large prefabricated housing estate) in Hungary. Nevertheless, it is evident that this common product of $20^{\text {th }}$-century urbanism was modified by local urban potential and socio-economic backgrounds. Budapest's new master plan drafted in 1960 (Kocsis 2008) defined territories for housing development such as Kelenföld or Zugló. Budapest's first Soviet housing factories began to produce in 1965, when planning and design were directed by new norms, panel-house technology and national economic requirements. As a result of this centrally-coordinated process, the first large prefabricated housing estate within the city was realized in Kelenföld, creating modern homes for human beings of the future. (Figure 1)

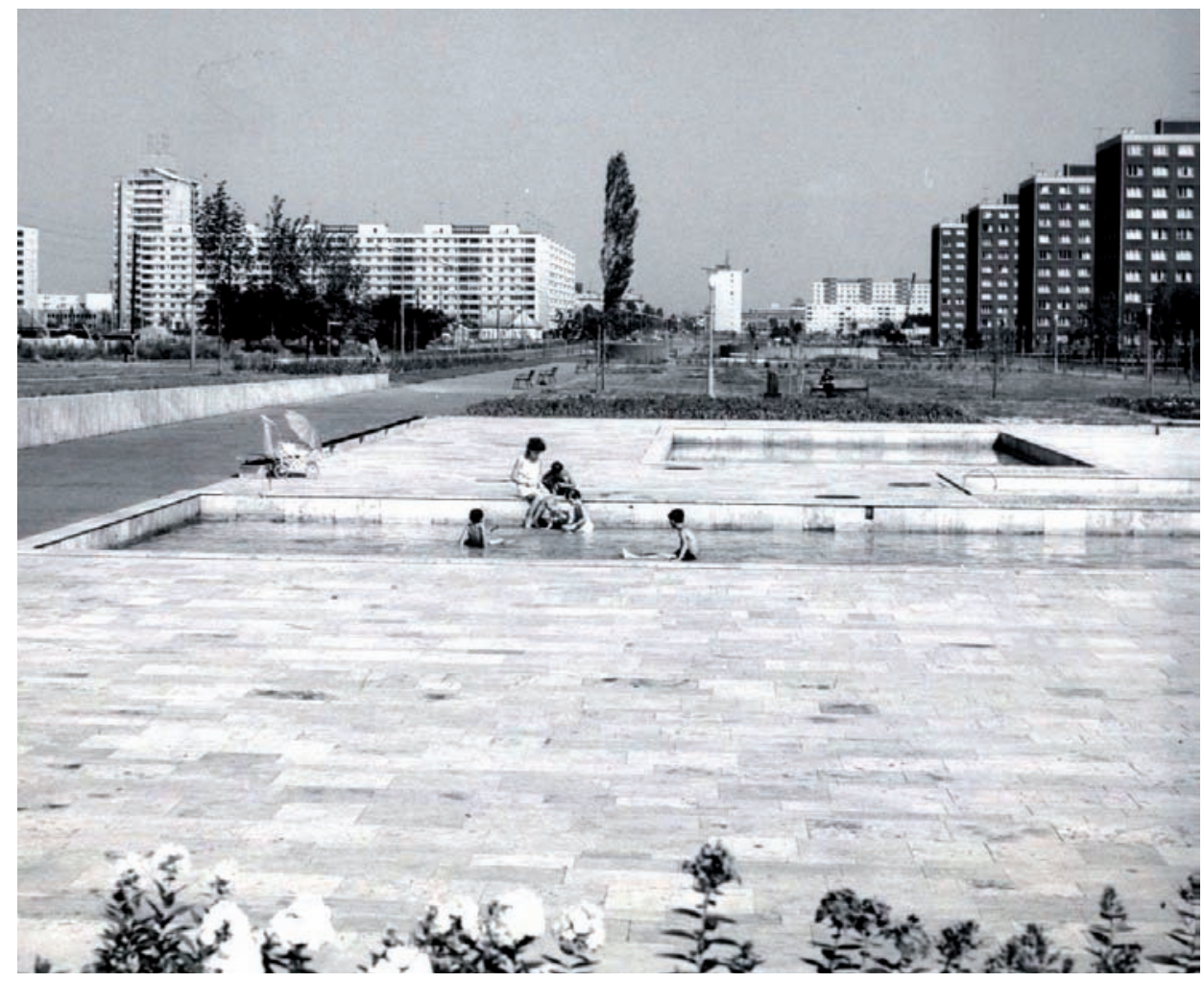

Figure 1. Kelenföld Housing Estate, Budapest, 1968. (From the photo collection of the Department of Urban Planning and Design, BME.) 


\section{Methods: Past, Present and Tomorrow}

Budapest tegnap, ma és holnap (Budapest Yesterday, Today and Tomorrow) - this is the title of a popular 16-minute long science film released in 1970 (Kollányi 1970). With the help of expert Charles Polónyi, architect-professor of the Department of Urban Planning and Design at the Budapest University of Technology and Economics (Polónyi 2004) and one of the ten professionals in the international Team 10 group, it explains the large prefabricated housing estate developments around and within the historic city center. Rearranging the order of the simple words used in the title of this film, the paper starts form the present situation, gives a brief overview of the past, and then focuses on the tomorrow.

Table 1.: matrix of material values in three scales

\begin{tabular}{lll}
\hline City of Budapest & Neighborhood & Building \\
\hline location & urban form & apartment \\
\hline position within the city & road network & size \\
natural characteristics & land use & spatial division \\
proximity & built volume & wet area \\
\hline infrastructure & facilities & technology \\
\hline energy & culture and education, & comfort \\
water & health and leisure activities & panel structure \\
waste & commerce & materials \\
\hline mobility & open space use & common spaces \\
\hline public transport & territoriality & doorway \\
car & green area & staircase \\
accessibility & motorization & roof \\
\hline
\end{tabular}

Taking the people's needs and Budapest's specific situation in relation to the challenges of sustainability as a starting point, the paper attempts to use the backcasting method based on social, economic and environmental trends. In defining a theoretically desirable future for this dominant type of urban housing as a sustainable urban neighborhood, the analysis works backwards. The assessment indicators of the physical environment are categorized within three different scales. The city level addresses the location, infrastructure and mobility opportunities in Budapest in relation to a housing estate; the neighborhood level focuses on the master plan, primary facilities and use of open space within a micro-district; while at the building level there is the residential panel building with its flats, technology and common spaces. Nevertheless, it is certain that all these compo- 
nents of the physical environment should be complemented with environmental, economic and social approaches to establish a complex system. Although in the Central and Eastern European literature, there are several good studies on large prefabricated housing estates focusing on economic and social aspects, also covering Budapest (Egedy 2000, Csizmady 2004, Tosics 2004, Molnár 2013); still, urban and architectural evaluation is lacking. (Table 1)

\section{Today}

In Hungary, the proportion of "panel" dwellings in the national housing stock is 20 percent, but in Budapest this ratio is higher. Approximately one third of the population lives in large prefabricated housing estates. Nowadays, they are mainly associated with negative images having to do with socialist lifestyle, estrangement and "panel" circumstances, in accordance with the post-industrial society's new political, economic, cultural and social ideas (Benkő 2014). Yet, the evaluation of the image, the perceived identity of the neighborhood by residents and the outside world, is often different. (Figure 2)

To describe today's situation objectively, the best method is to take a look at the prices. Comparing the average price per square meter $(\mathrm{m} 2)$ between used apartments constructed with panel technology and non-panel technology, the difference is huge. In 2014, the panel is only 181,000 HUF per m2, as opposed to the others at 290,000 HUF per m2. Among the panels, the most expensive units are on the Buda side, built at the end the panel period in the 80s (Pók utca - 226, 000, Gazdagrét - 211,000). The cheapest lie in the transitional belt or on the outskirt of the city on the Pest side, built during the mass production of the 70s (Havanna - 125,000 m2, Újhegy - 126,000, Pesterzsébet - 130, 000) (OTP 2014). This is despite the fact that the Havanna Housing Estate - one of the most stigmatized estates in Budapest (Csizmady 2004) - initiated an "integrated social urban rehabilitation program” co-financed by the European Union and Hungary in 2009. Roughly 40,000,000 Euros of public money were spent on the renewal of the physical and social environment. Nevertheless, it is very difficult to work against the stigmatization, because image is generally more important than reality. Obviously, the well-known slogan of the real estate developers, "location, location, location”, applies to the evaluation of large prefabricated housing estates, too. (Figure 3) 


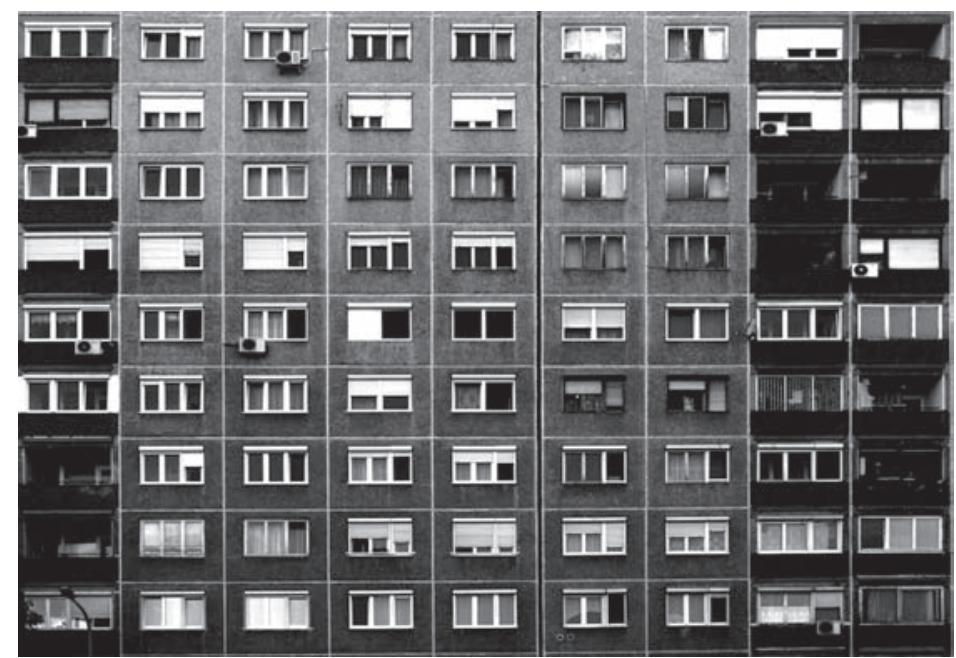

Figure 2. Typical soviet prefab building in Óbuda, Budapest, 2014. (Fabian Toth's photo.)

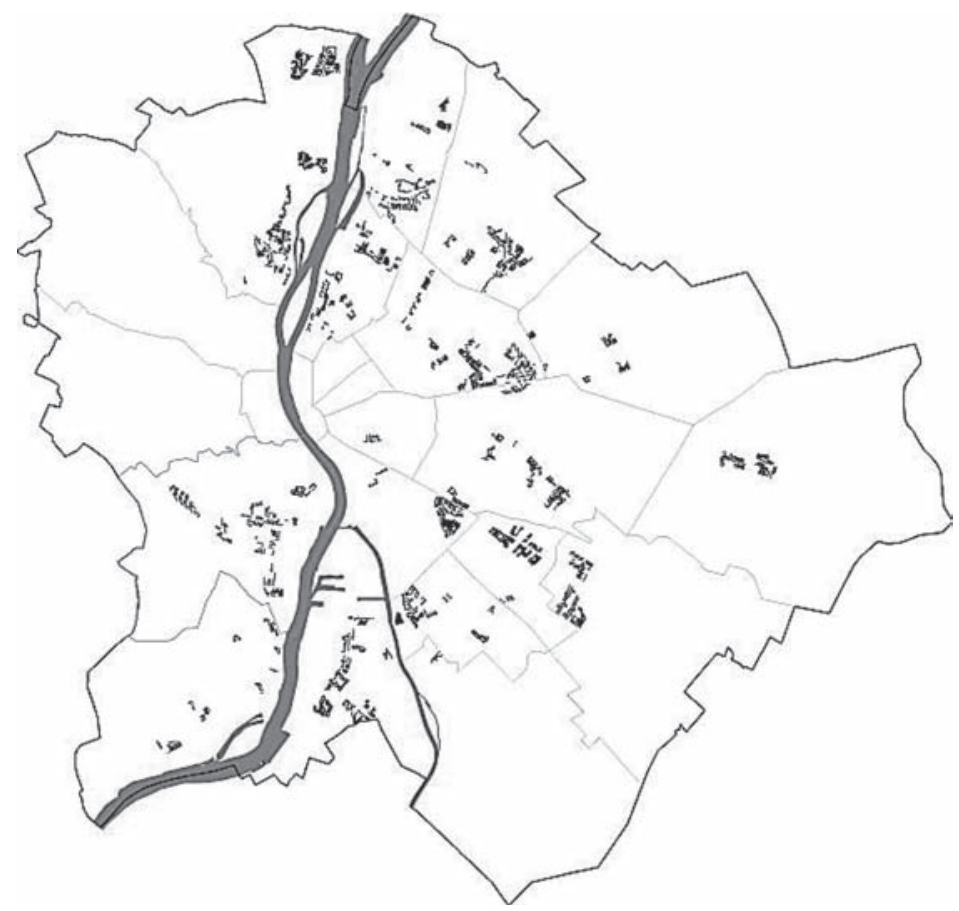

Figure 3. Location of large prefabricated housing estates in Budapest. (Author's figure based on Judit Rab’s drawing.) 


\section{Yesterday}

The standardization, industrialization and prefabrication of apartment buildings, as well as the construction of large housing estates or new towns, were global phenomena that seemed an efficient solution to the post-war housing shortage. Not only Communist politicians, who promised apartments for every family to create a socially just society, but urban planners and construction designers were also enthusiastic about utilizing and developing in practice the international housing policy and architectural theory (Nagy 1968). What is more, it was actually prestigious to live in this modern environment, one which seemed to offer inhabitants superior physical housing conditions and a better quality of life. The home became a present of the State, and, as the Hungarian proverb states: "Don't look a gift horse in the mouth.” Living in a panel apartment was simply the norm, and their values were not questioned (Muliuolyré 2013). National and international publications that covered this progress confined themselves to objective and comparative figures like the number of developments (Werner 1975). The large prefabricated housing estate became a homogeneous product of Communist cities throughout Central and Eastern Europe. No attention was paid to country, city or neighborhood characteristics, while people were mere users of this new comfort.

Nonetheless, criticism appeared following the first realization. First, in 1969, two sociologists from the Hungarian Academy of Sciences published a book on the social problems created by new panel housing estates (Konrád \& Szelényi 1969). Then, recognizing also some negative economic consequences of the mass housing policy, national politics changed the system. The last year for the State's "present” of a free home for all was 1971 (Körner \& Nagy 2006). Last but not least, planners and architects with no hope of any radical change - since panel technology and mass production were coordinated at the national level and the sector occupied a very strong political and economic position - discussed the urban and architectural problems recognized in housing estates. After quantity, the quality of living conditions became a question. During the preparation period of the second fifteen-year housing policy (1976-1990), new professional initiatives appeared. The first real discussion about panel aesthetics, the so-called Tulip discussion, occurred in 1975, when the façades of the building and their position in the landscape came into focus (Kissfazekas 1998). Simultaneously, architects were searching to find design solution to realize more flexible plans on neighborhood, building and apartment levels, too. In 1976, a new catalogue for panel buildings appeared with some small opportunities for innovation: corner sections to allow more complex urban compositions, as well as apartments for different households to accommodate multi-generational families, large families or single people. Technology followed new demands, only slowly. The famous "E" panel family with a 5.40 m panel structure was not realized until 1982 (Körner \& Nagy 2006). 
The first urban and architectural history overview of Budapest's large prefabricated housing estates was published in 1998, defining 26 mass housing units constructed during the Hungarian panel period between 1965 and 1991 (Preisich 1998). Without giving a complete list, there are some curiosities. The first was in Kelenföld, composed mainly of 10-storey "ribbon" buildings using Soviet panels with 3.20 m units. Óbuda Center, with the same technology, received the longest Hungarian slab, the 338-meter-long Faluház. Újpalota, using the Team 10 project theory, became the biggest with 15,400 units for approx. 60,000 inhabitants. Havanna is well-known because of its criminological stigmatization. Gazdagrét was promoted by the first actual Hungarian soap opera, Szomszédok (Neighbors), at the end of 80s; while Káposztásmegyer, situated on the northern outskirts of the city, was constructed as the last huge product of panel housing factories. (Figure 4)

After the change of the political and economic regime, the position of the large prefabricated housing estate changed absolutely. First and most importantly, the national housing stock, including the panels, was privatized in the 90s. Every building became an independent condominium with many owners. The number of owners varied between 16 (in smaller 4-storey panel towers) and 886 (in the biggest 10-storey slab, the Faluház in Óbuda). Together, they were responsible for building maintenance, potential development of common spaces, technical installation, the façade, the roof, etc. However, residents bought not only their

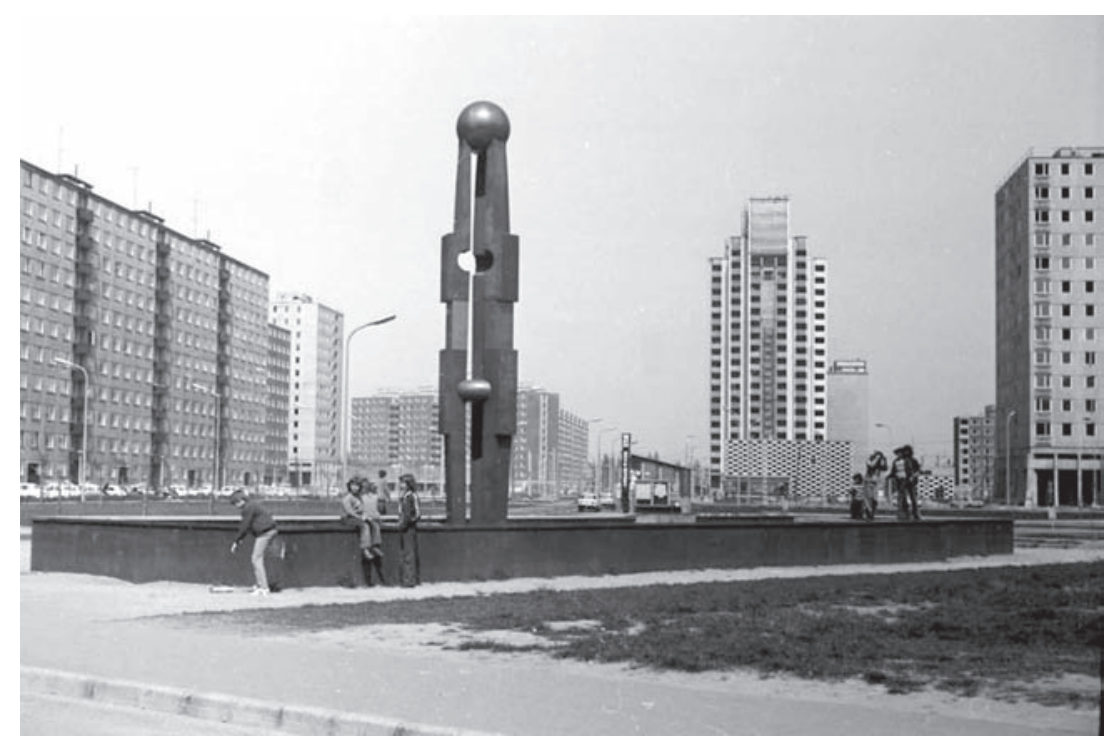

Figure 4. Újpalota Housing Estate, Budapest, 1974.

Available at: Fortepan http://www.fortepan.hu/ [Accessed 11 March 2015]. 
flat, but also all the problem inherent in ageing panel buildings. Second, ageing is also an important factor in terms of the residents. The young generation of the 60s, 70s and 80s, who received their first panel flat to raise two children and live as a typical communist middle-class family using the facilities provided by the state, are now middle-aged, if not elderly. The majority live in the same flat, in pairs or alone, their children having left the neighborhood; while new residents use the area without this natural attachment of childhood, just as a cheap transitional home in their lifetimes. In general, shrinkage has characterized the large prefabricated housing estates of Budapest since the mid-90s. Third, the lifestyle has changed completely. Economic and cultural globalization, new types of individualization, digital technologies, etc., provoke more and more social differentiation. In the heterogeneous world, everybody tends to reject the homogeneity represented by the physical appearance and the central heating of panel buildings. People who have the opportunity move away; those who cannot continue to reside there and feel segregated. In any case, the image of prefabricated housing estates has become quite negative. Finally, the only element which has not changed is the open space system. It belongs to the district municipality as a public territory in which the buildings float. This situation has resulted in problems represented by new phenomena related to socio-economic background - for example, maintenance cost, change of space use, accessibility, parking shortage, increased number of dogs, crimes and feelings of insecurity as well.

\section{Tomorrow}

Now, 25 years after the transition period, the question is how the large prefabricated housing estates that we have inherited could become an integrated part of Budapest's future. In recent years, after the well-known and widely-used building evaluations, sustainable neighborhood assessment systems have begun to be created (for example, the CASBEE-UD from Japan, the BREEAM Communities from the UK, the DGNB-UD from Germany or the LEED-ND from the US), seeking scientific, objective and measurable fundamentals for new worldwide urban development (Szabó 2012). A recent study comparing the different mandatory and optional indicators of these internationally recognized assessment tools found that criteria focus upon three aspects: the location of the development, the ecology of the neighborhood and the technology of the buildings (Orova \& Reith 2013). Nevertheless, the developers of new sustainable urban neighborhoods creating and using the assessment systems are not really interested in regeneration. It is sure that, in the case of existing large prefabricated housing estates, the location within the city and the panel technology are inherited; yet, given the economic, environmental and social challenges in Central and Eastern Europe, every com- 
ponent of matrix of the material values has a potential for sustainability. It is the time to recognize this model, to discuss it and use it! (Table 2)

In post-Communist countries, the large prefabricated housing estates stand up well, and this type of modern housing remains dominant for a long time. Thus, their future depends on the geopolitical situation of the country and the city, on the local housing policy, on demographic changes, and on the property system established by the different privatization systems after the political and economic changes of 1990. It is impossible to generalize this urban challenge. The processes diverge sharply not only among Central and Eastern European countries (for instance, demolition is typical in the former East Germany, technical renovation is obligatory in Poland, restitution had a special physical impact in Latvia,

Table 2. Potentials of material values in three scales for sustainability

\begin{tabular}{|c|c|c|}
\hline City of Budapest & Neighborhood & Building \\
\hline location & urban form & apartment \\
\hline $\begin{array}{l}\text { re-use of urbanized land } \\
\text { proximity } \\
\text { intensification }\end{array}$ & $\begin{array}{l}\text { Environmental sustainability } \\
\text { sustainable transport } \\
\text { high density }\end{array}$ & $\begin{array}{l}\text { ownership transformation } \\
\text { adaptability to social changes } \\
\text { accessibility }\end{array}$ \\
\hline \multicolumn{3}{|l|}{ Infrastructure - technology } \\
\hline $\begin{array}{l}\text { high density } \\
\text { energy efficiency } \\
\text { smart development } \\
\text { renewable energy use } \\
\text { water management } \\
\text { waste management }\end{array}$ & $\begin{array}{l}\text { high density } \\
\text { energy efficiency } \\
\text { smart development } \\
\text { renewable energy use } \\
\text { water management } \\
\text { waste management }\end{array}$ & $\begin{array}{l}\text { compactness } \\
\text { energy efficient renovation } \\
\text { smart development } \\
\text { renewable energy use } \\
\text { water management } \\
\text { changing character }\end{array}$ \\
\hline \multicolumn{3}{|l|}{ Mobility } \\
\hline \multirow[t]{3}{*}{$\begin{array}{l}\text { high density } \\
\text { energy efficiency } \\
\text { rapid transport development } \\
\text { sustainable transport } \\
\text { smart development }\end{array}$} & $\begin{array}{l}\text { high density } \\
\text { inter-modality } \\
\text { permeability } \\
\text { sustainable transport } \\
\text { smart development } \\
\text { community building } \\
\text { facilities } \\
\text { rich mix of uses } \\
\text { adaptability to social change } \\
\text { community buildings }\end{array}$ & $\begin{array}{l}\text { sustainable transport facilities } \\
\text { accessibility } \\
\text { smart development } \\
\text { community building }\end{array}$ \\
\hline & open space use & common spaces \\
\hline & $\begin{array}{l}\text { environmental sustainability } \\
\text { car-free zones } \\
\text { greenery } \\
\text { walkability }\end{array}$ & $\begin{array}{l}\text { adaptability to social changes } \\
\text { accessibility } \\
\text { attractiveness } \\
\text { changing character }\end{array}$ \\
\hline
\end{tabular}


etc.), but also among cities within the same country and housing estates within the same city (Temelová et al. 2011). The large housing estates in Berlin, thanks to urban growth, function well. Meanwhile, the majority of the housing stock in panel buildings has already been demolished in some estates situated on the outskirts of Magdeburg. In Hungary, large prefabricated housing estates demand different policies in prospering cities (such as Budapest, Székesfehérvár or Sopron) and in former industrial or new towns where shrinkage seems to be irreversible. In Budapest, as today's situation reflects perfectly, the location of the micro-district is and remains forever the most important issue: location within Europe, within the country, and the city, too. This location is fixed, but for sustainability, it is of utmost importance to re-use this urbanized land. Intensification, transformation, renewal and demolition could be tools. In the Central and Eastern European context, policymakers, developers and designers are responsible for confronting the complexity and disorder of existing urban areas in order to build complex sustainability.

Beside urban scale re-use, the other main indicator of sustainability in every assessment system is high density. The large housing estates were developed according to standards, to achieve the optimal density for the development of modern infrastructure: central heating, water systems, waste management, public transport, etc. It is evident that in the future, efficient management and smart development of existing infrastructure is one of the key challenges. The infrastructure, with its hierarchical organization, is the backbone for relationships along the city, neighborhood and building scale. The "green" elements of Budapest's public transport system provide rapid transit by metro, HÉV (suburban railroad) and train for several large prefabricated housing estates. For example, Kelenföld and Örmező are privileged by the new metro line, the M4 development in 2014; M3 serves Újpest, Angyalföld, and the József Attila housing estate directly; and the HÉV connects Békásmegyer, Pók utca, Óbuda and Csepel with the center. Still, there are isolated large prefabricated housing estates without any good transit opportunities, and their future depends on public transport development at the city level. Káposztásmegyer was built without the promised metro connection at the end of the 80s, the new metro line (M4), opened in 2014, has not yet reached Újpalota or Gazdagrét. Nevertheless, some housing estates perhaps can never be an integrated part of a sustainable public transport system (such as Havanna, Kispest, or the Centenárium Housing Estate). They remain far away from the main arteries of the city.

International literature uses the sustainable urban neighborhood (SUN) term as a new urban design model for the 21st century (Rudlin et al. 1999). Following the SUN characteristics, it is evident that the large prefabricated housing estates are perfect in some general respects for intense high density, environmental sustainability, permeability and walkability. Other components or qualities (such as location, transit opportunities and urban blocks) depend on the specific neighbor- 
hood; however it is evident that the majority of weaknesses are community and function based. Location and good transit are city-level questions, but planning and design solutions made for a large prefabricated housing estate constitute two principal fields of the sustainable urban neighborhood: green mobility and environmental sustainability. It is important to recognize that large prefabricated housing estates are ideal sites to introduce new systems maintaining the original car-free and green open spaces of the micro-district (Fiala \& Locsmándi 1981). Low-speed options (such as tram, hybrid or electronic bus, bicycle, walking or others solutions) combined with special intelligent technology (such as car-sharing and car-pooling) demand responsive transport solutions and can provide easily sustainable transport in areas that are dense enough at the neighborhood level. However, panel buildings and public open spaces have to be able to adapt to new functions related to sustainable transport on their ground floors and in former parking areas (bicycle storage, offices, CNG and electric vehicles chargers, etc.). Green transport has the potential to become a main value of prefab estates, playing an important role in the community building, in the management of open spaces and also in the transformation of "fundamental spaces", the slabs and towers (Balla 2014). (Figure 5)

Large prefabricated housing estates were designed as a new urban unit liberated and independent from the surrounding environment. Nevertheless, the urban form of these neighborhoods varies by period and site. For example, due to adaptations in modern architectural theory, the buildings are stand-alone masses in a vast, continuous open space. There are no traditional urban contexts any more: no streets or blocks, no public or private areas, no building locations (corner building or neighboring buildings) in the traditional sense. The majority of mass housing in Budapest constructed in the 60s and 70s used this common international solution, though modified by local conditions. For example, in Kelenföld Housing Estate, they created a huge green center on the space of a former construction site. Újpalota is organized along a large main green axis, and Békásmegyer
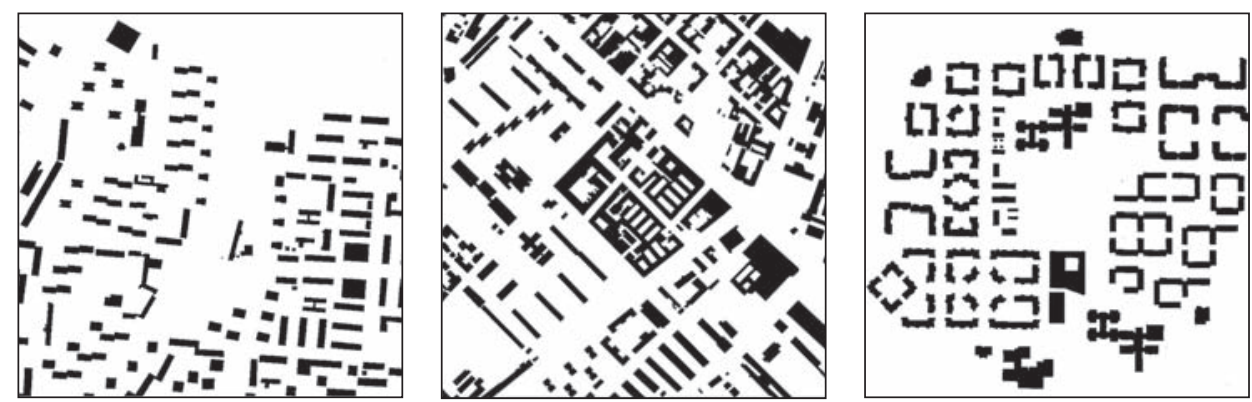

Figure 5. Urban form from the 60s, 70s and 80s. József Attila, Tüzér utca and Káposztásmegyer Housing Estates. (Author’s drawing after city maps; same scale, orientation to the north.) 
approaches the bank of the Danube River, etc. Afterwards, in the projects of the 80s, postmodern architecture appeared, re-evaluating the importance of open space division both in terms of form and use. For instance, in Pók utca or Káposztásmegyer, they reinvented the courtyard system to make it feel like a semi private territory of the surrounding buildings.

According to the contemporary international discussion about sustainable urban form (Salat 2011), large prefabricated housing estates are extremely valuable in terms of environmental sustainability. On the one hand, the ratio of built area to active green surface is quite good thanks to standard regulations that set aside 14 $20 \mathrm{~m} 2$ of green space (playground, tree line, public green area, etc.) per resident (Preisich 1998). On the other hand, the quality of open spaces is also favorable, because, at the time of construction of the homogenous panel world in Budapest, interventions of the landscape architecture played an important role in humanizing the new neighborhoods. In the 70s, more the $70 \%$ of the Hungarian landscape architectural projects were in prefabricated housing estates, creating intense vegetation, organic space division and sometimes new topography (Bakay 2012). Besides having an environmental impact (off-setting climate change, developing biodiversity and water management at the neighborhood level, and so on), today and in the future, these open spaces can be an integrated part of the local socioeconomic life as well. Green open space can adapt new functions as different types of urban agriculture. It influences the everyday feelings of users and makes the neighborhood more appealing by establishing a contact to nature. (Figure 6)

Another big issue regarding the sustainable future of large prefabricated housing estates is energy efficiency. The majority of the European and national programs focus on this objective socio-economic aspect, since utility costs have risen dramatically. Additionally, the renovation of simple panel surfaces is easy to implement, and the results are immediately measurable (Hrabovszky-Horváth \& Szalay 2014).

After EU accession in 2004, beside the technical renovation (exterior insulation, change of windows and modernization of the heating system), the reduction of carbon dioxide emissions and the use of renewable energy also became important. Approximately one third of the panel housing stock has been renovated, but due to privatization and the public procurement method, the change is not on the neighborhood but on the building level. It is certain that - by utilizing existing infrastructure and the high density nature of mass housing, introducing complex technological solutions and educating people to be more energy conscious - large prefabricated housing estates have plenty of potential to create a more energy efficient urban neighborhood and a more sustainable city of Budapest.

Last but not least, it is important to recognize some merits of the prefab buildings. The new phenomenon of individualization, the changing family structure and new types of housing (for example, co-housing) can facilitate the use of small 


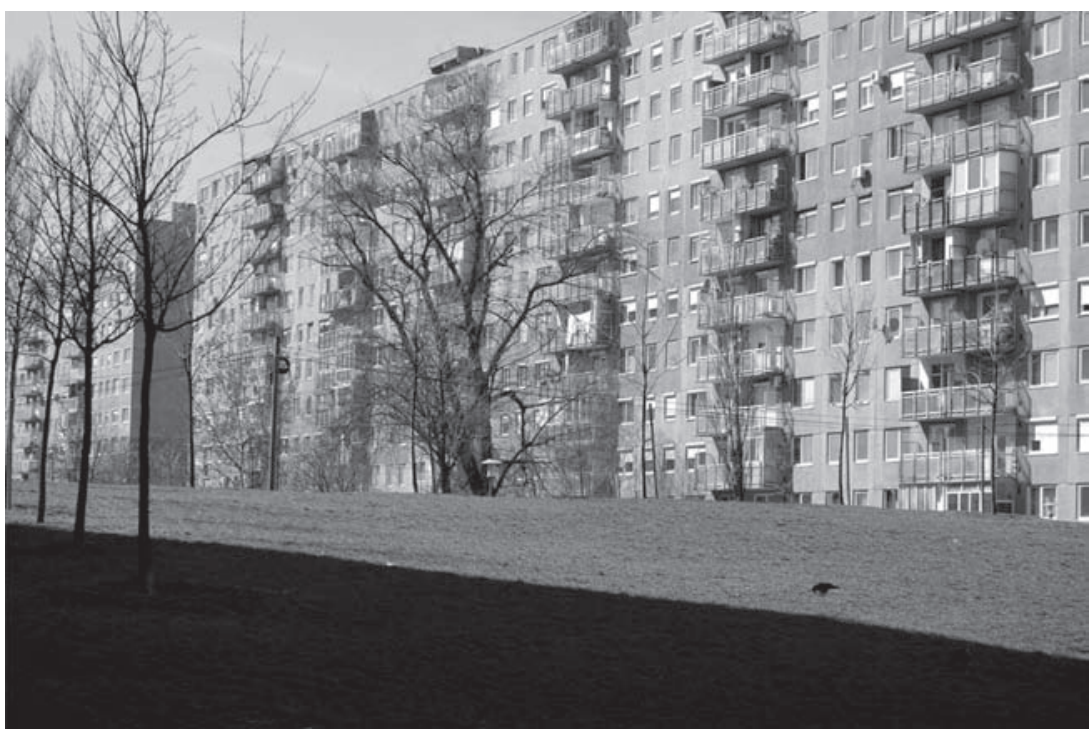

Figure 6. Havanna Housing Estate, Budapest, 2014.

(Author's photo.)

and compact apartments (average two rooms, approx. $50 \mathrm{~m} 2$ ). In the 10-storey slabs and higher towers, lifts can provide accessibility for all. The ageing society of prefab neighborhoods provides an opportunity to reorganize the ownership system, develop the lack of common spaces and uses on the ground floor, create new apartments at the extreme parts of the building (for example, the top floor or at the corners), and invite new residents into the area (Csízy 2012). Realized already in Germany, the complex physical regeneration, complemented by media promotion of the new panel life, can attract the private sector, ensure a self-healing process and aid in image-building for the reevaluation of potentials. Nonetheless, the key to the future lies not in the immaterial values, but in the consciously discovered and well-coordinated development of material components. This is capable of spurring positive change in Budapest's large prefab housing estates.

\section{Conclusion}

At the time of panel estate constructions, the Hungarian Communist system centrally coordinated everything: the planned economy, the housing policy and the construction industry. International urbanism and architecture combined elements to create a new living environment. Now, 50 years after the start of the first extensive mass housing program in Budapest, the European Cohesion Policy for 
the period 2014-2020 is attempting to introduce a method of integrated sustainable urban development (EU 2013).

\begin{abstract}
The various dimensions of urban life - environmental, economic, social and cultural - are interwoven, and success in urban development can only be achieved through an integrated approach. Measures concerning physical urban renewal must be combined with measures promoting education, economic development, social inclusion and environmental protection. In addition, the development of strong partnerships between local citizens, civil society, the local economy and the various levels of government is a pre-requisite. (European Commission, 2013, p. 2)
\end{abstract}

Yet, it is clear that integration should have a different meaning today than during the time of large centrally-planned prefabricated housing estates. The question is how it is possible to develop an appropriate sustainable future for one third of the Budapest population residing there, how to make participants cooperate to manage and compromise present needs, and how the immaterial (soft) and material (hard) values and deficiencies of this modern urban heritage can be recognized. To achieve the purpose of SUN (sustainable urban neighborhood), both types of integration, the vertical and the horizontal, are indispensable. As the tables of this study show, there are many aspects to be integrated. The keywords have not changed, but the contents of contemporary urban life are brand new. Within the vertical integration, the historic and spatial urban unit, the neighborhood, needs to remain central. Complex area-based renewal is very important, since behind the hard panel solutions, which tend to be similar, the soft human components are really quite different. Regeneration can be promoted by European, national or city programs, but it has to be coordinated by the city of Budapest; and without the residents of the building condominiums and responsible local professionals prepared to find compromise, it will never be successful. The film Budapest tegnap, ma és holnap (Budapest Yesterday, Today and Tomorrow) highlighted the importance of the transformation of urban and social fabric by new prefab housing estate developments around 1970; however, the current urban renewal process seems to be more complicated and problematic than new investments. In Europe and in Budapest, however, this is the real challenge for sustainable urban future.

\title{
Acknowledgement
}

This work was supported by the Hungarian Academy of Sciences under Grant Bolyai [number BO/00162/13/6]. 


\section{References}

Bakay, Eszter. 2012. Tértagolás kertépítészeti eszközökkel a budapesti lakótelepek szabadterein 1950 és 1990 között. In: Fenntartható fejlödés, élhetö régió, élhetö települési táj 3. Budapest: Budapesti Corvinus Egyetem.

Balla, Regina. 2014. Horizontális hézag - a paneles lakóházak földszintje. Budapest: BME. Available at: http://tdk.bme.hu/EPK/DownloadPaper/Horizontalis-hezag-a-paneles-lakohazak [Accessed 21 March 2015].

Benkő, Melinda. 2014. Evaluating Factors in the Image of Housing Estates. Periodica Polytechnica Architecture, 43(1), 33-36.

Csizmady, Adrienne. 2004. A lakótelep. Budapest: Gondolat.

Csízy, László. 2012. A mikrostruktúra lehetőségei: Újpalotai közösségfejlesztés. In: Cságoly, Ferenc (ed.) Közösség és építészet. Budapest: BME Építőművészeti Iskola, 75-81.

Egedy, Tamás. 2000. The Situation of High-Rise Housing Estates in Hungary. In: Kovács, Zoltán (ed.) Hungary towards the 21st Century - the Human Geography of Transition. Budapest: Studies in geography in Hungary (31), 169-185.

European Commission. 2013. Integrated Sustainable Urban Development, Cohesion Policy 20142020. Available at ttp://ec.europa.eu/regional_policy/index.cfm/en/information/publications/ brochures/2014/integrated-sustainable-urban-development [Accessed 21 March 2015].

Fiala, István and Locsmándi, Gábor. 1981. Új lakóterületek belső közlekedési rendszere, Településtudományi Közlemények (30), 42-80.

Hrabovszky-Horváth, Sára and Szalay, Zsuzsa. 2014. Environmental Assessment of a Precast Concrete Building Stock in a Time Perspective. Environmental Engineering and Management Journal, 13(11), 2997-2804.

Kissfazekas, Kornélia. 1998. A tulipán-vita. Kortárs építészet, 1(1), (Online), Available at: http:// arch.et.bme.hu/arch_old/korabbi_folyam/kortars1.html\#4 [Accessed 25 March 2015].

Kocsis, János Balázs. 2008. Városfejlesztés és városfejlődés Budapesten 1930-1985. Budapest: Gondolat.

Kollányi, Ágoston. (director of the documentary film) 1970. Budapest tegnap, ma és holnap. Budapest: Mafilm. Available at: https://www.youtube.com/watch?v=BZTrtXYTD3w [Accessed 13 March 2015].

Konrád, György and Szelényi, Iván. 1969. Az új lakótelepek szociológiai problémái. Budapest: Akadémiai Kiadó.

Körner, Zsuzsa and Nagy, Márta. 2006. Az európai és a magyar telepszerü lakásépítés története 1945-töl napjainkig. Budapest: Terc Kiadó.

Molnár, Virág. 2013. Building the State: Architecture, Politics, and State Formation in Postwar Central Europe, New York: Routledge.

Muliuolyte, Justina. 2013. Rediscovering Large Scale Housing Estates in post Socialist Cities, Journal of Architecture and Urbanism, 37(1), 51-58.

Nagy, Elemér (ed.). 1968. Budapesti újabb lakótelepek városrendezési tervei. Magyar Építőmüvészet 1968(1), 20-26., (5), 20-35.

Orova, Melinda and Reith, András. 2013. Comparison and Evaluation of Neighborhood Sustainability Assessment Systems. Munich: PLEA 2013: Sustainable Architecture for a Renewable Future (Online), Available at: http://mediatum.ub.tum.de/doc/1169262/1169262.pdf [Accessed 13 March 2015].

OTP, 2014. Lakóingatlan értéktérkép 2014/2. (Online), Available at: https://www.otpbank.hu/ OTP_JZB/file/Ertekterkep_Lakoingatlan_2014_2.pdf [Accessed 13 March 2015].

Polónyi, Károly. 1992. An Architect-Planner on the Peripheries. Budapest: Terc. 
Preisich, Gábor. 1998. Budapest városépítésének története 1945-1990. Budapest: Műszaki Könyvkiadó.

Rudlin, David, Falk, Nicholas and URBED. 1999. Building the 21st Century Home: The Sustainable Urban Neighbourhood. London: Architectural Press.

Salat, Serge. 2011. Cities and Forms: on Sustainable Urbanism. Paris: Hermann.

Szabó, Julianna. 2012. A települési fenntarthatóság mérése. In: Alföldi, György, ed. Budapest 2050 - a belvárosi tömbök fennmaradási esélyei. Budapest: Terc.

Temelová, Jana, Novák, Jakub, Ouredníček, Martin and Puldová, Petra. 2011. Housing Estates in the Czech Republic after Socialism: Various Trajectories and Inner Differentiation, Urban Studies, 48(9).

Tosics, Iván. 2004. European Urban Development: Sustainability and the Role of Housing. Journal of Housing and the Built Environment, 19(1), 67-90.

Werner, Rietdorf. 1975. Neue Wohngebiete sozialistischer Länder. Berlin: Verlag für Bauwesen. 